\title{
The National Organization of Science in France (1896-1939) or the Institutional Enterprise as a Compromise
}

\author{
Gabriel Galvez-Behar Université de Lille - SHS - IUF \\ Abstract \\ Key words
}

\section{Introduction}

The concept of institutional entrepreneur allows us to highlight the ability of actors to mobilize resources which are not necessarily exclusive to their field of activity. These resources are then used to create institutions that will address collective action and, where appropriate, provide new resources. Unlike other forms of entrepreneurship, institutional entrepreneurship responds to what is an effectively collective goal, even if this is not pursued by the entire collectivity that it claims to serve. Such a notion can only be used by specifying exactly the collectivities at work, taking into account the specific features of the fields examined particularly when actors move between domains.

The historical approach responds to this need insofar as it focuses on particular factors over time, but not only. It also allows us to consider entrepreneurial activity as a more or less longterm process, thus detaching it from a short-term approach centred on single individuals. While the biographical approach is vital when it comes to understanding the aspects of entrepreneurial activity, we should avoid the charm of the individualist idol (Simiand 1903). By considering the processes over several generations, the historical approach allows us to examine the collective dimension of entrepreneurship and the phenomena of transmission and interruption within the internal logic underpinning such activity.

This article illustrates the importance of this approach by focussing on enterprises in French science organized at a national level between 1896 and 1939. Dealing with the scientific field requires an additional preliminary observation; discussing entrepreneurship in the scientific domain does not automatically give us an ahistorical definition of the latter. It may be tempting to try and link the concept of institutional entrepreneurship to the field of science using notions inspired by an inapt use of mertonian sociology (the production of original knowledge and its values: communalism, universalism, disinterestedness, etc.) (Merton 1973). These characteristics are not so much timeless properties of science as elements of an ideal-type taken 
as a yardstick of historical reality. In other words, there is no time-free definition of science, but there are representations that refer to activities considered as scientific over time (Pestre 2015). The potential of the notion of 'institutional entrepreneur' thus depends on what we make of it in any particular field; its importance lies in the outcome of enquiry, not in its precursor.

We also need to identify the specific context. In this respect, French science in the first half of the 20th century was characterized by very specific traits: a strong relation with a particularly centralized state, a weak university system, a much more accentuated level of individualism than in other countries because of a lack of collective scientific work, an enduring lack of means, and a strong engagement in a process of emulation at the international level. These last two features partly explain the recurring attempts to organize or reorganize French science, starting with the university reforms in 1896 to the creation of the National Centre for Scientific Research (Centre national de la recherche scientifique, CNRS) in 1939. At the national level these reforms must be distinguished from local initiatives which, although far-reaching, did not introduce systemic change by integrating institutions at the national level.

Are these national reforms, which lie at the heart of the discussion, the product of institutional enterprises? In order to respond to this question, we need to clarify things a little. The historiography has long stressed the key role of the group that emerged around Marie Curie, Jean Perrin and Paul Langevin in the organization of French science in the early 20th century (Weart 1979, Picard 1990, Pestre 1992, 1997). This group, the so-called Arcoest group after the Breton village where several of its members spent their holidays, often appears as a common thread linking several major reforms. To what extent can we, from then on, regard it as a collective institutional entrepreneur? Or should we take other actors into account and focus on the process of institutionalization of French science as the result of the process setting up competing enterprises?

The first part of this article examines the creation of the Fund for Scientific Research (Caisse des recherches scientifiques, CRS), one of the first reforms of French science and recalls the role of an institutional entrepreneur, Jean Audiffred, whose links with the reformist milieu were vital at the time. The second part focuses on World War I where another group, gathered around the figure of Paul Painlevé, exploited the war to lay the foundations for a new organization of science. This enterprise, built up in continuity with prior initiatives, ran counter to other rival projects. The final part returns to the main stages of the reorganization of science and the conflict between two key actors who succeeded in creating the CNRS in 1939, JulesLouis Breton and Jean Perrin. 


\section{The Locations of Reformist Science}

At the end of the 19th century French science was experiencing a marked yet contrasting development with a series of reforms which were unable to satisfy the scientific community. The creation of the Practical School for Advanced Studies (École pratique des hautes etudes, EPHE), thanks to the initiative of the historian and minister Victor Duruy, was already an indication of the state's commitment to promoting scientific research (Weisz 1983). The 1896 university reform was the outcome of changes carried out under the Third Republic when some large provincial towns encouraged the setting up of new scientific institutions (Nye 1986). Yet this effort fell well short of the needs of a community engaged in a form of international competition. In addition, historiography often overestimates the influence of the state. The search for real autonomy led to the creation of the Pasteur Institute in 1888 based on private donations. Nevertheless, in the early 20th century, philanthropy alone was unable to meet the financial demands of science and the prize system was unable to provide financing for increasingly costly research (Crosland and Gàlvez 1989). In this context, institutional arrangements were needed once more.

\section{The Fund for Scientific Research}

The La Caisse des recherches scientifiques (CRS) was created by the law of 14 July 1901 to meet this need (Pinault 2006). It was the result of five years' work by a republican deputy, JeanHonoré Audiffred (1840-1917). A lawyer be training, Audiffred developed expertise in the domain of agronomy thanks to the development in his own estate. This interest in agronomy and his election as deputy to the National Assembly in 1879 allowed him to support measures of agricultural modernization using a scientific approach. For Audiffred, policy-making was a science (Pinault 2006, 22) and this conviction led him to encourage scientific research. As a member of the Insurance and Social Welfare Committee (Commission d'assurance et de prévoyance sociale) which drafted the law on mutual protection societies, in 1896 Audiffred proposed a law to finance research in the faculties of medicine. This evolved from the reformist goals of the milieus to which Audiffred belonged: the best way to guarantee the continuity of newly-established social institutions set up to combat mortality was to harness the expertise of medicine. Although the proposal met with fierce opposition from those who were against any extension of state powers, and was abandoned, it was nevertheless a milestone.

Audiffred was re-elected in 1898 and submitted a new bill in 1900 for the creation a Fund for Scientific Research for pure science not only in medicine, agriculture and veterinary science, but also in other domains like physics or chemistry. The context was conducive to the adoption 
of this measure because other initiatives were being activated at the same time. The National Academy for Arts and Crafts was endowed with a new experimental laboratory thanks to the socialist Minister of Trade and Industry, Alexandre Millerand (Galvez-Behar 2008). Audiffred's new proposal was thus rapidly adopted and became law on 14 July 1901.

The remit of the Fund for Scientific Research was to raise funds and in particular, starting in 1902/3 it received a small part of the revenues of the Pari mutuel - the French Tote - and in exchange it subsidized scientific research. For over thirty years, it fulfilled this task, albeit hampered by a chronic lack of financial backing. Although it seemed to have a simple and ingenious' financing mechanism (Paul 1985, 306), the CRS's action was limited by its inadequate means due to the reluctance of donors and the determination in some political milieus to curb public expenditure. Moreover, the functioning of the Fund was based on a rather narrow notion of what support to grant (Pinault 2006), even if some scientists benefitted from above average support.

The CRS was a new institution with resources which were rather scattered. Actually it funded a very small number of scientific entrepreneurs of whom Albert Calmette (1863-1933) was one of the most emblematic. After studying medicine he entered the navy's health service, and then spent several periods in the French colonies before joining the Pasteur Institute in 1890. Shortly after he was sent to Saigon to set up a branch of the Institute and in 1895 he was given the task of creating a Pasteur Institute in Lille. As director of this new institute in 1899, he pursued his research not only on tuberculosis but also on water purification and set up a sewage treatment plant with strong local backing, and the support of the CRS which awarded him 220,000 francs from 1903 to 1907 , equivalent to one third of resources distributed in that period, thanks to a special subvention. To a great extent, the CRS tried to respond to the demands of the 'nébuleuse réformatrice' of the early 20th century (see Topalov 1999) and favoured scientific enterprises developing along reformist lines.

\section{Scientific enterprise and social reform}

As Michel Pinault has shown, Honoré Audiffred was strongly involved in an influential institution in early 20th century France, the Musée social. This was set up in 1894 as a place to reflect on, and to promote, social reform using a scientific approach (Chambelland 1998; Horne 2002). In 1911, with the President of the Union Textile Employers, Robert Carmichaël, a section on economic studies was created within the Musée social. This involved politicians, civil servants, industrialists but also scientists such as the mathematician Paul Appell, the biologist Maurice Caullery, the chemists Henry Le Chatelier and Charles Moureu, and the 
physician and bacteriologist Fernand Widal. At the time such a coalition was not in the least unusual, but its task was original - using science and innovation to resolve social issues.

Before the war, the economic studies section addressed the role of science in industrial production. The debate developed around a report submitted by Henry Le Chatelier (18501936), which generated an intense reaction in favour of the organization of science (Letté 2004). Le Chatelier was a lecturer at the prestigious École Polytechnique, and a big name in metallurgy in the early 20th century France. He was the creator of the Revue de métallurgie, consultant for private companies, and the promoter of industrial science that he tried to disseminate through the Society for the Promotion of National Industry (Société d'encouragement pour l'industrie nationale). For him it was a question of using re-organized scientific methods and applying them to industry. It comes as no surprise that he was also the propagator of Frederick Taylor's work in France (Fridenson 1987; Letté 2004; Henry 2013). In sum, Le Chatelier also appeared to be a man of science and an institutional entrepreneur.

The section of economic studies at the Musée social gave Le Chatelier a platform for his ideas on the organization of science and how to make it more effective. This goal, however, meant abandoning the postulate according to which 'science with a capital $\mathrm{S}$ is not to be regimented' (Le Chatelier 1914 88). According to him, scientific research needed to act on new rules and in line with a research programme set up by a committee of scientists and industrialists. Le Chatelier rejected the romantic vision of science in favour of organized science.

On the eve of World War I, Audiffred's institutional enterprise allowed him to set up institutions where science was not only considered a social policy stake, but where the organization itself constituted a stake. It is worth noting that the institutions where Audiffred was involved took initiatives and in turn became a locus of conflict between competing enterprises. Le Chatelier's project was not compatible with that of Audiffred. The Fund for Scientific Research was based on an individualist vision of science whereas Le Chatelier's goal was to regiment it. Thus, we cannot understand institutional enterprises without examining the competition among them. This is even more necessary when another group of entrepreneurs intervenes in this reorganization of French science on the eve of World War I.

\section{A Dreyfusard science?}

Scientific entrepreneurship refers to a field of activity with idiosyncratic traits. We cannot understand French science in the early 20th century without taking into account the Dreyfus affair that divided society in general and the scientific community in particular. This political 
crisis took place from 1894 to 1906 and dealt with the unfair prosecution of army captain Alfred Dreyfus. A lot of intellectuals denounced the falsified documents, on which the accusation was based. In a sense, the Dreyfus affair was also a scientific controversy. The mathematician Paul Appell (1855-1930), who played a key role in organization projects, was convinced of Dreyfus' innocence from 1897 (Appell 1923, 208). Paul Painlevé (1863-1933), also a mathematician, took longer to be convinced, but was nevertheless in the front line in the campaign to defend Captain Dreyfus. Both epitomize the Dreyfusard scientists from the milieu of the École normale supérieure. They formed the core of a solid group and were joined by a third mathematician, Émile Borel (1871-1956). In 1901, Borel married Paul Appell's daughter with whom he founded the Revue du mois, a scientific and literary journal in which Painlevé collaborated along with the physicists Jean Perrin and Paul Langevin. This group (the Revue du mois group) then of Arcoest was to play a major role in the organization of French science.

These political and personal affinities were reinforced by shared scientific convictions. Painlevé and Borel were both interested in applied mathematics and their scientific investigations led them to focus on the subject of aeronautics. Drawing on his research on mechanics and the subject of friction, Painlevé gave the first course in fluid mechanics at the newly created Higher School for Aeronautics and Mechanical Construction (École supérieure d'aéronautique et construction mécanique, ESACM) inaugurated in 1909. The same year, he started a campaign to promote aeronautics and the following year he published a work on aviation with Borel. Finally, Painlevé was also involved in the creation of the Aerotechnical Institute (Institut aéronautique) in Saint-Cyr which then hosted research on aerodynamics (Anizan 2012). His election as republican-socialist deputy in 1910, in which Appell and Borel took an active part, allowed Painlevé to step up his action. As a member of the Committee of Air Navigation at the Ministry of Public Works, he developed an increasing interest in national defence issues. In 1912, Painlevé held the positions of member of the Military Aviation Committee, member of the so-called Commission des poudres in the Ministry of War and was budget rapporteur for the navy in the National Assembly. His involvement in aeronautics also allowed him to step up relations with France's military milieus.

In the eyes of a man of science such as Painlevé, promoting this industry new meant working with science in aid of the nation; the rallying cry which had united French scientists after the defeat of 1871. The commitment was now clearer and more explicit, with a scientific, industrial and political dimension. Without doubt, the Dreyfus affair played a key role in all this. The Dreyfusard scientists stepped up relations with political figures who had remained in the forefront during the Belle époque. In defending the ideal of an open science, they clearly 
proclaimed their social role. They took part in the development of industry which symbolized technical progress and which was a guarantee of national defence, thus accomplishing the mission that they set for themselves (Pestre 1997).

On the eve of World War I French science was the focus not of one but of several institutional enterprises. Three in particular stand out: that of Audiffred, that of Le Chatelier and that of the so-called Painlevé group, although these hide others which can only be revealed by a detailed historical analysis. These enterprises diverged and at times competed and to understand them better we have to take these games of alliance or opposition into account. Each of them had a collective dimension. Each was generally associated with an individual entrepreneur Audiffred, Le Chatelier, Painlevé - , but the latter appears to be more of a symbol of a collectivity than the head of a particular enterprise.

From then on we need to compare the configurations of each of these enterprises and to stress their most salient features (see Table 1). It is important to note that the most striking realization, in spite of its failures, originated outside the academic field while those originating solely in academia only were only partially implemented. The 'École' that Le Chatelier managed to create after his appointment to the Sorbonne in 1907 was more of an invisible college than an institution in the strict sense (Letté 2004). As regards Painlevé, his plans for a national laboratory of aviation were only partly realized with the creation of the Institut aéronautics in Saint-Cyr in 1911 thanks to the industrialist and patron Henry Deutsch de la Meurthe. Indeed, in the national reorganization of science the political powers had the upper hand in determining the budgets of universities and large institutions. A scientific enterprise could only succeed if it managed to find the means necessary thanks to philanthropy or public funding. Donations to science were sometimes very high in France, but they were rare in the early 20th century (Marais 1999, chapter 6). Resorting to the state was thus a way to circumvent a relative lack of resources, but one that required strong political support. The success of a nationwide scientific institutional enterprise only occurred thanks to the very particular relation of scientific entrepreneurs with the world of politics.

Table 1: Three institutional enterprises in the domain of French science in the early 20th century

\begin{tabular}{|l|l|l|l|}
\hline & \multicolumn{1}{|c|}{ Audiffred } & \multicolumn{1}{c|}{ Le Chatelier } & \multicolumn{1}{c|}{ Painlevé } \\
\hline Core group & $\begin{array}{l}\text { National Republican } \\
\text { Association (political } \\
\text { movement) } \\
\text { Musée social }\end{array}$ & $\begin{array}{l}\text { Revue de métallurgie } \\
\text { (importance of engineers) }\end{array}$ & $\begin{array}{l}\text { Associated with the milieu of } \\
\text { the École normale } \\
\text { supérieure, and the Revue du } \\
\text { mois }\end{array}$ \\
\hline Hierarchical organization & Horizontal & $\begin{array}{l}\text { Vertical with Le Chatelier in } \\
\text { a dominant position }\end{array}$ & $\begin{array}{l}\text { Horizontal with Painlevé in a } \\
\text { strong position }\end{array}$ \\
\hline Scientific involvement & $\begin{array}{l}\text { Indirect via links with the } \\
\text { milieus of agronomics, }\end{array}$ & $\begin{array}{l}\text { Strong links in chemistry and } \\
\text { engineering }\end{array}$ & $\begin{array}{l}\text { Strong links in mathematics } \\
\text { and physics }\end{array}$ \\
\hline
\end{tabular}




\begin{tabular}{|c|c|c|c|}
\hline & Audiffred & Le Chatelier & Painlevé \\
\hline & $\begin{array}{l}\text { health-related issues and } \\
\text { chemistry }\end{array}$ & & \\
\hline Political involvement & $\begin{array}{l}\text { Direct via Audiffred's } \\
\text { election to the National } \\
\text { Assembly }\end{array}$ & $\begin{array}{l}\text { Indirect via networks such as } \\
\text { the section of economic } \\
\text { studies at the Musée social }\end{array}$ & $\begin{array}{l}\text { Direct involvement in the } \\
\text { Dreyfus affair and the } \\
\text { election of Painlevé to the } \\
\text { National Assembly }\end{array}$ \\
\hline Economic involvement & $\begin{array}{l}\text { Strong via links with the } \\
\text { milieu of employers (Musée } \\
\text { social) and the chemical and } \\
\text { food industries }\end{array}$ & $\begin{array}{l}\text { Strong relations via his work } \\
\text { as a consultant with large } \\
\text { enterprises }\end{array}$ & $\begin{array}{l}\text { Moderate links in aeronautics } \\
\text { (an emerging sector) }\end{array}$ \\
\hline $\begin{array}{l}\text { Symbolic } \\
\text { achievements }\end{array}$ & $\begin{array}{l}\text { Fund for Scientific Research } \\
\text { (Caisse des recherches } \\
\text { scientific, CRS) }\end{array}$ & $\begin{array}{l}\text { Revue de métallurgie, } \\
\text { the 'École' of industrial } \\
\text { science set up under the chair } \\
\text { for chemistry at the Sorbonne }\end{array}$ & $\begin{array}{l}\text { École supérieure } \\
\text { d'aéronautique et des } \\
\text { constructions mécaniques } \\
\text { (course on mechanical } \\
\text { aviation) }\end{array}$ \\
\hline
\end{tabular}

\section{World War I, an institutional opportunity}

World War I upset these subtle relations by prioritizing the plans of scientists who not only mobilized for the war effort, but also manoeuvred to obtain key political positions in government for themselves. The war was the opportunity to move forward with the organization of science for war by creating institutions required by the conflict. This time the 'Painlevé group' clearly had the upper hand.

\section{An Undersecretary of State for Inventions, an institutional innovation}

The mobilization of experts in the service of national defence did not start with World War I. It dates back at least to the revolutionary wars and the Franco-Prussian war of 1870 which witnessed a brief collaboration between the military, experts and inventors and that continued throughout the Third Republic (Crosland 1976, Roussel 1989, Bret 2002). From the start of the conflict, to the initiative of Paul Appell, the Academy of Sciences undertook to coordinate research on national defence (Belot 2000). The first year of the war thus witnessed men of science mobilized for the national war effort which meant the establishment of institutions responding to needs which had appeared pre-war. In fact, the engagement of the Academy of Sciences in the conflict largely reflects the drive for reform that was already evident before the war.

The development of these institutions reached a turning point when Painlevé was appointed Minister of Education, Arts and Inventions relating to national defence in November 1915 and the creation, in this new ministry, of the Department of Inventions for National Defence 
(Roussel 1989; Galvez-Behar 2005; Anizan 2012). ${ }^{1}$ The creation of this direction was the main reason for Painlevé's appointment in this ministry. It consisted of fifty members - including five academics, nine university professors, and ten civil engineers — but Painlevé's group stood out with Émile Borel as head of the technical office, assisted by Jean Perrin. The Department for Inventions encouraged scientific research, financed it, evaluated inventions and sometimes developed them. Painlevé and his group were not only at the heart of the scientific mobilization but made a vital contribution to its organization (Anizan 2012, 155-156).

Political hazards should nevertheless be taken into account. The formation of a new government in December 1916 left Painlevé out of power but saw the creation of an Undersecretary of State for Inventions to which the Department was attached. The deputy JulesLouis Breton was then appointed Undersecretary of State. The new figure responsible for inventions was not unknown in the political and scientific world (Moissinac and Roussel 2012). Breton (1872-1940), was a deputy for Cher who had studied chemistry and held a place of assistant at the Collège de France in the early 1890s. In 1897, he launched a journal to disseminate scientific knowledge and alongside his scientific activities he was also an active militant. Founder of a group of revolutionary socialist scholars, he was first elected deputy for the socialists in 1898 and gradually move closer to Alexandre Millerand. This support came at the cost of being excluded from the French Socialist Party in 1910. Breton then joined the Republican-Socialist Party close to Millerand and Painlevé. Elected as a member of the board of directors of the Fund for Scientific Research in 1912, he introduced a budget amendment to boost the Funds' financial resources. As a member of the High Commission for Inventions (Commission supérieure des inventions) in 1914, he carried out research on a device to cut through barbed wire. Breton's footing in the scientific and political milieus, his involvement in the CRS and his political and personal proximity to Painlevé explain his appointment as new Undersecretary of State for Inventions in 1916.

With the Undersecretary of State for Inventions, the men of science appointed by Painlevé acquired greater influence and had the upper hand over frequently hostile technical-military bodies. In 1917, the Undersecretary of State for Inventions evolved with the political rise of Painlevé. When the latter became Minister of War in 1917, the Undersecretary of State was renamed and its functions were much reinforced. ${ }^{2}$ When Painlevé became Prime Minister in September 1917, the Undersecretaryship of State for Inventions returned to his authority under

1 Journal officiel de la République française, 14 Nov. 1915, report to the President of the Republic and Decree of 13 Nov. 1915, p. 8,200.

2 Journal officiel de la République française, 21 April 1917, Decree of 14 April 1917, p. 3,163. 
the Ministry of War. ${ }^{3}$ The arrival of Painlevé as head of government thus allowed for a concentration of technical-military services for study under the authority of a civil authority and with the active participation of experts and inventors.

Yet, the Department of Inventions, then Undersecretaryship of State, did not have a straightforward development and was heavily contested by antagonistic forces among civil society and the military and between supporters of competing or even clashing enterprises. After Painlevé's resignation in November 1917 the institution became more vulnerable and Jules-Louis Breton had to face increasingly strong criticism. The Undersecretary of State reverted to being a simple department under the Ministry of Armaments which exercised a strict, and even wary control over its activities. Yet, because the social and political demand remained strong, Breton was able to maintain this institution of scientific mobilization. Indeed, in the context of the war and once the Department of Inventions had been created, no governmental official would take responsibility for suppressing a structure which was an engine for victory. Privileges could be restricted and the lost influence army could be restored, but it would have been unthinkable to go backwards. Painlevé's merit was to have used his position to enforce the institution; that of Breton was to have kept it going. The institutional enterprise rests here on the attempt to profit from conditions of the moment to permanently consolidate any steps taken.

\section{The initiatives of Le Chatelier in the Academy of Sciences}

World War I constituted a very particular context, and it certainly did not erase the competition of institutional enterprises that had emerged before the war. Henry Le Chatelier tried to promote his plans to reorganize science to the Academy of Sciences, which had been one of the first scientific institutions to be involved in the conflict. In November 1915, during a secret committee of the Academy of Sciences, Le Chatelier insisted on the need to support industrial science and to assign him a sum of money. ${ }^{4}$ Some months later, he called on the Academy to 'be more actively involved in the direction of research' in subsidizing laboratories on the basis of a scientific programme. ${ }^{5}$ In 1916, he proposed that the Academy take the lead in reorganizing existing scientific bodies and suggested setting up a commission to draft a report on the ways and means to develop scientific methods in industry. The idea was met with general approval and the proposal was accepted and a new body, the Committee for External Action

3 Journal officiel de la République française, 16 Sept. 1917, Decree of 14 Sept. 1917, p. 7,732.

4 AS, Secret Committee, record n. 7, meeting of 22 Nov. 1915. In 1911 the industrialist Auguste Loutreuil died and bequeathed over 7 million francs to various scientific institutes three of which under the aegis of the Academy of Sciences.

5 AS, Secret Committee, record n. 7, meeting of 17 Jan. 1916. 
(Commission d'action extérieure), was set up to prepare a report. With Le Chatelier, the commission brought together half a dozen members of the Academy several of whom including the chemist Albin Haller and the mathematician Émile Picard — had already declared themselves in favour of reconciliation between science and industry before the war. ${ }^{6}$

In line with a plan proposed by Le Chatelier, the work of the new commission dealt with three types of issues: the organization of large laboratories for research in industrial science; changes in teaching methods; and the organization of work in factories, thanks to industrial laboratories and the impact of Taylorism. ${ }^{7}$ Yet in the end the commission focused on two basic issues: setting up a national laboratory of physics and mechanics and the creation of a new section within the Academy. The Commission's plans vied with those of Painlevé as the Minister of Education. Starting in autumn 1916 Painlevé planned the creation of a national office of applied sciences whose primary role would be to provide information and to coordinate and reinforce the links between science and industry (Anizan 2012, 170-175). The project failed due to Painlevé's departure from the Minister of Education in December 1916, but his successor, René Viviani, reported back to the Academy of Sciences. ${ }^{8}$ He judged that the two projects were not incompatible per se, but stressed the difficulty to provide the means necessary for both of them if implemented at the same time. Le Chatelier's plan and Painlevé's plan clearly competed with one another.

The other question addressed by the Academy was the creation of a section dealing with the application of science to industry. André Blondel, who had studied at the École Polytechnique and with whom Le Chatelier was linked through his activities as a consultant, proposed that the Academy create five places for renowned figures in the domain of industry or the application of science to industry. ${ }^{9}$ The idea was taken up by a committee for external action (Commission d'action extérieure) and sparked intense debate. We have to wait until January 1918 for the creation of a section on 'Applications of Science to Industry' within the Academy of Sciences. ${ }^{10}$ The election of members of the new section was the chance to witness the influence of Henry Le Chatelier at work with his three candidates - Auguste Rateau, Maurice Leblanc and Georges Charpy - while Georges Claude, even if defended by Paul Appell and Paul Painlevé, was not elected. ${ }^{11}$

6 AS, Secret Committee, record n. 7, meeting of 22 May 1916.

7 AS, DG 46, Committee of External Action, meeting of 16 June 1916.

8 AS, DG 46, letter of 19 Feb. 1917 from the Minister for Education to the President of the Academy of Sciences.

9 AS, Secret Committee, record n. 7, meeting of 22 May 1916.

10 AS, Secret Committee, record n. 7, meeting of 14 Jan. 1918.

11 AS, Secret Committee, record n. 7, meeting of 6 May 1918. 
This opposition between these two institutional enterprises took place against the backdrop of an attempt to reorganize French capitalism initiated on the eve of the war and which gathered speed during the war thanks to Étienne Clémentel, who was appointed Minister of Trade and Industry in 1915 (Druelle-Korn 2012). Yves Roussel has demonstrated Clémentel's interest in projects developed in the Academy of Sciences (Roussel 1985). In 1917, taking up the projects of Le Chatelier, Clémentel then suggested reorganizing the National Conservatory for Arts and Crafts (Conservatoire national des arts et métiers, CNAM) and merging it with the laboratory planned by the Academy and that of the Electricians' Society (Société centrale des électriciens) (Roussel 1985, 38-40). Providing France with good laboratories became one of the goals of Clémentel's team; a team which from then on was to include Le Chatelier, thus giving the institutional enterprise the benefit of political support.

By the end of World War I the institutional enterprises of the Belle époque had produced contrasting results. Painlevé's enterprise was clearly a success. It profited from the needs and opportunities generated by the war, and exploited his political position acquired before the war, He managed to set up an organization to promote the science of war, an enterprise which was clearly motivated by patriotism and had to operate within strict military constraints. The fact remains that its implementation rested, albeit not entirely, on plans drawn up before the war. The war allowed the pursuit of a project by other means and, obviously, in another context. In particular, it provided Painlevé's enterprise with support for further developments.

When it comes to Le Chatelier, the successes are far less evident. But here too, the project planned from 1914, albeit reformulated, was not abandoned and the troubled backdrop of war facilitated the emergence of new alliances and new positions. The uncertainty generated by war also created opportunities and the fact that Le Chatelier seized these opportunities emphasizes the entrepreneurial dimension of his approach. War brought actors from different fields together: on 'the other front' (Fridenson 1977), the military, politicians, industrialists and experts mixed more closely than before. This change in the relational context brought institutional scientific entrepreneurs even more resources than the war had done (MacLeod 2009). With the war over institutional entrepreneurs had to adapt to a new context.

\section{From one enterprise to another: the reorganization of French science in the interwar period}

The reorganization of French science between the two wars is often presented as a success story for the institutional entrepreneur in the shape of Jean Perrin. Perrin achieved his goals thanks to his convictions in favour of 'pure science' and his political support (Weart 1979, Morize- 
Charpentier 1997). In fact, this individualistic or heroic vision of institutional entrepreneurship is already undermined by the preceding analysis. No institutional enterprise can be understood without referring to competitors and, finally, the collective dimension is essential. Also, describing an institution needs to figure the various contradictory forces which are embedded in it. No more than another, no scientific institution can be conceived as a demiurgic creation of scientific entrepreneurs. Thus the conventional narrative about the creation of the CNRS in 1939 has to be revised.

\section{An Impossible Compromise: the National Office for Scientific and Industrial Research and Inventions, Office national des recherches scientifiques et industrielles et des inventions (ONRSII)}

The creation of the CNRS is often presented as an answer to the failure due to the WWI legacy. Actually, in the wake of World War I there were several competing projects to reorganize French science and in December 1918 an interministerial commission was set up to find a compromise. This forty-man commission was presided over by Clémentel himself with Millerand, Painlevé and Picard as vice-presidents and three sub-commissions. ${ }^{12}$ The first dealt with the construction of new national testing laboratories and tried to bring the experimental laboratory of the CNAM and the Central Laboratory of Electricity closer together by setting them up in the same place in a suburb of Paris. The second sub-commission focused on the creation of a laboratory of the Academy of Sciences. Le Chatelier wrote the report calling for the institution of a laboratory of the Academy of Sciences to pursue 'general research, without an immediate industrial objective' attached to the National Office of Scientific, Industrial and Agricultural Research and Inventions (Office national des recherches scientifiques, industrielles, agricoles et des Inventions, ONRSII). This project was dealt with by the third sub-commission presided over by Painlevé. In the report submitted by the deputy Henri Pottevin, the future National Office was supposed to develop and coordinate applied scientific research, while guaranteeing studies demanded by government and assisting inventors. Each report was accompanied by a bill. When it completed its work early in 1919, the interministerial commission drafted a general plan to accommodate competing projects.

Yet the government only submitted one bill in 27 May 1919 and this was based on a report by the deputy Henri Pottevin (1865-1928) who had been a key actor in the interministerial commission. Pottevin was a physician, chemist and biologist, a former member of the Louis

12 Work of the Interministerial Commission set up by the Interministerial Decision of 7 Dec. 1918, 398 AP 23, National Archives. 
Pasteur laboratory and then the Pasteur Institute. He was also a Dreyfusard, specialized in questions of hygiene and in 1909 became secretary general of the International Office of Public Hygiene. In 1914 he was elected deputy for Tarn-et-Garonne, he chaired the Nitrogen Commission in 1917 and worked with the Department of Inventions. To some extent the figure of Pottevin is comparable to that of Painlevé: a politician-cum-scientist. It is however necessary to note that the bill he submitted in May 1919 was the only one of three projects drafted four months earlier to have a parliamentary follow-up. Pottevin's project differed nevertheless from the original project in some respects. The new Office was to be a financially independent public body to promote, coordinate and encourage not only applied research, but all scientific research. The Department of Inventions and the Fund for Scientific Research were connected even if the latter preserved its autonomy. It looks as though the bill tried to make a synthesis of three earlier projects.

The bill was adopted by the National Assembly on 10 July 1919, but it took over three years for the Senate to approve it; it was finally enacted on 29 December $1922 .{ }^{13}$ Meanwhile, the Department of Inventions was under attack and only managed to resist attempts to destabilize it thanks to the action of its head, Jules-Louis Breton. More than ever, Breton turned out to be a the pillar of the new institution. Like Painlevé or Pottevin, he was a bridge between the scientific and political milieus, and particularly between different stages of the process of the institutionalization of science in France. Of course, the compromise in the shape of the Office ran the risk of not satisfying anyone, but it was still a significant step forward. This is clear from the fact that it acquired the status of public institution with legal standing contrary to the original plan in 1919, and had financial and legal autonomy. It could rely on a national council made up of representatives of expert bodies, learned or technical societies and industrial groups. All told, the Office was an institutional innovation (Blancpain 1974; Chatriot 2006, 2013).

This is not the place to discuss how the Office functioned especially as some works already give us a good idea (Moissinac and Roussel 2012). However, we should highlight some of its features. ONRSII clearly corresponded more to the needs of Painlevé than to those of Le Chatelier for while its mission was to coordinate research it was not based on a precise scientific programme. The idea was instead to respond to the needs of all parties in an, on the whole, very open-ended perspective. The other feature of the Office was its tendency to promote research with a strong industrial dimension, which led, as we have seen, to the expectations expressed around the figure of Clémentel. The judgement, however, that the Office failed to satisfy those who wanted to encourage 'pure science' needs to be re-evaluated by recalling that on the eve of

13 Journal officiel de la République française. Lois et décrets, 30 Dec. 1922, p. 12,462. 
the war Jules-Louis Breton put the ONRSII at the service of the Academy of Sciences in order to realize a large electromagnetic project (Guthleben 2009). The ONRSII played a large part in financing the installation of this extensive plant which housed the work of its promoter, the physicist Aimé Cotton, as of 1928 (Shinn 1993). Thus the Office tried to respond to the needs expressed support in research, especially when it came to pure science (Paul 1985).

\section{From the Perrin Plan to the creation of the National Centre for Scientific Research}

At the same time as one sequence put in motion by World War I came to a close, the creation of ONRSII opened up another. As an institutional compromise generated by different logics, the Office only partially responded to the needs of a scientific community damaged by the war and worried by the financial prospects. Faced with galloping postwar inflation, the state was unable to guarantee universities funding comparable to that of prewar period: in 1921, the budget for universities in real terms was equivalent to a little under 80\% of the 1913 budget (Pestre 1992, 308). Faced with this disastrous economic situation, a new scientific mobilization was necessary and other institutional enterprises emerged around the figure of the physicist Jean Perrin (Charpentier 1997). Perrin had graduated from the École normale supérieure, was associate professor of physics, a Dreyfusard and member of the Painleve group, and in the early 20th century he was known for his work on the atom. At the Sorbonne, where he was appointed in 1910, he was opposed by Le Chatelier who found his work too theoretical. During World War I he was actively involved with the Undersecretary of State for Inventions thanks to his work on tracking, particularly sonar tracking. With the war over, Perrin became a leading figure in the reorganization and financing of science.

Without going into detail about this campaign, we should recall the milestones and the role played by Perrin and his group (Picard 1990, chapter 2). The creation of a foundation by Baron Edmond de Rothschild in 1921 and the launching of an appeal for private donations with a day in honour of Pasteur in 1923 (la journée Pasteur) were the two first steps of this mobilization based on philanthropy. The latter produced effects since the Rothschild Foundation financed the creation of the Institute of Physico-Chemical Biology (Institut de biologie physico-chimique) in 1927 with Perrin as its president. Although it played a vital role, generosity, private or public, was not enough. In 1924 Émile Borel was elected deputy for the French Radical Party and the following year pushed through a bill to reform the apprenticeship tax to help subsidize laboratories. The political context clearly counted since the Prime Minister at the time was Édouard Herriot, an alumnus of the École normale supérieure and a personal friend of Jean 
Perrin. ${ }^{14}$ A further step was taken in 1930 when Perrin presented a plan for a 'National Scientific Research Service' to finance grants, allowing researchers to devote themselves entirely to their scientific work free of teaching commitments (Picard 1990, 34-42).

At this point we should recall the time it took to develop this project until the final establishment of the CNRS in 1939. The National Fund for Science (Caisse nationale des sciences) was created in 1930. Its original goal had been to finance the pensions of scientists, but then it was made responsible for awarding research grants (Frédéric Joliot-Curie, Langevin’s pupil, was one of the first beneficiaries). Three years later, in April 1933, the National Research Council (Conseil supérieur de la recherche scientifique) was set up to 'facilitate disinterested research' and to advise on how to organize such research. ${ }^{15}$ In 1935, Pierre Laval's government merged the functions of the Fund for Scientific Research and the National Fund for Science to create a National Fund for Scientific Research. The enterprise led by Perrin increased momentum when he was nominated Undersecretary of State for Scientific Research from September 1936 to June 1937. Under the Popular Front government and thanks to the support of the Minister of Education, Jean Zay, Perrin managed to obtain a significant increase in the research budget and the retirement of Jules-Louis Breton, thus hastening the closing down of the ONRSII.

The fall of the Popular Front government in 1937 did not stop the progress of the enterprise which had developed around Perrin, but it did make its course more tortuous. The High Council for Scientific Research became the locus of collective reflection on the organization of science. In 1938, it voted to reinforce the links between pure and applied science that the sluggishness of the French economy and international tensions made ever more necessary. A legislative decree of 24 May 1938 thus created the National Centre for Applied Scientific Research (Centre national de la recherche scientifique appliquée, CNRSA) replacing the ONRSII and with a High Committee responsible for coordinating research in pure and applied science. Unlike the Office, the CNRSA's task was to plan research in a context of impending hostilities. It thus echoed the model proposed twenty-five years earlier by Le Chatelier. In April 1939, a decree allowed the National Fund for Scientific Research to set up laboratories. Finally, on 19 October 1939, a decree led to the creation of the CNRS by merging the CRS, the CNRSA and the National Fund for Scientific Research (Service central de la recherche scientifique) to make the action of different institutions more efficient and in the interests of 'good management'. ${ }^{16}$

14 Journal officiel de la République française. Débats parlementaires. Chambre des députés, 24 Feb. 1925 , p. 1,177 .

15 Journal officiel de la République française. Lois et décrets, 15 April 1933, p. 3,871.

16 Journal officiel de la République française, 24 Oct. 1939, p. 12,594. 


\section{Enterprises, competition, compromise}

The process that led to the creation of the CNRS in the 1930s merits some comment. The role of Jean Perrin had been crucial, but we should resist the temptation to portray him as the champion of French science. It is true that he had a key role thanks to his scientific standing, his political support and his membership of the so-called Arcoest group. His relations with Édouard Herriot and then with Jean Zay were also key resources when it came to turning his plans into legislation. We can also assume that Perrin's influence grew following the death of Paul Painlevé in 1933. This generational change, exemplified by the gradual exclusion of Jules-Louis Breton, largely due to Perrin himself, brought about a change in the core of a group which had been so active in 1914.

The importance of Perrin's role should not, however, hide the fact that the creation of the CNRS was the result of a plurality of logics (Blancpain 1974). Perrin did not create his project alone and it was only one of several. Many projects were initiated in the 1920s and if we know little about their outcome, it is precisely because the historiography focuses on Perrin. In any case, his project gave rise to counterproposals that echo the situation of competition during World War I. Obviously, the terms of competition between different projects were not the same and it would be mistaken to think that Perrin's plans would have would be introduced on its own. Perrin's project was also redefined during its implementation to the point that we ask ourselves whether the attributions of paternity on the subject should not be discussed. It would be interesting to rewrite a narrative of the Le Chatelier project up to the creation of the CNRS showing that an a priori programming of science never disappeared during the period. The question of the relation between pure and applied science is also quite revealing. While Perrin is supposed to have based his project on the promotion of pure science, the rivalry among different projects and the demands of the time (the economic crisis, preparation for war) meant that great importance was given to applied science. The CNRS thus appears as a compromise between differing logics, and between different projects and it is not surprising that its creation gave rise to a debate on how to interpret its (Guthleben 2013).

The fusion of different institutional enterprises nevertheless had significant results. Not only had the organization of science become the major focus of scientific research - as testified to by its place in a journal such as the Revue scientifique - but the representation of learned bodies had changed. The Academy of Sciences no longer played a key role. This was instead played by the High Council for Scientific Research (Conseil supérieur de la recherche scientifique) and the High Committee for Coordination (Haut comité de coordination). Even 
before World War II, the institutionalization of science had become a key stake for the scientific community.

\section{Summary and Conclusions}

The history of institutional enterprises which contributed to the organization of French science in the first half of the 20th century confirms the key role of some groups beginning with the Painlevé-Borrel-Perrin group. More generally, it highlights the importance of 'parliamentary savants' (Moissinac and Roussel 2012) who built up a dominant position in the academic field and an important place in the political field. Painlevé, Pottevin, Perrin and, to a lesser extent, Audiffred and Breton were bridges between the two milieus. The combination of these two positions allows easier access to public resources, and not only financial resources. Bearing in mind the role of the state in structuring higher education and research in France, a political position reinforces the legal capacity to set up new organizations and offers better access to public funding and private philanthropy. This double position in the economic and political fields was as fruitful as it was rare in the scientific field (Charle 1994). Alternatively, a strong link between a scientist and a political figure, similar to that uniting Perrin and Herriot, can play a similar role.

This need to resort to alliances explains why we cannot reduce an institutional enterprise to a sole entrepreneur, for three reasons. First, the entrepreneur, just like the enterprise, is by nature collective even if a retrospective discourse tends towards some degree of personification. The $a$ posteriori personification of an enterprise can erase this collective dimension, although it is precisely this dimension, characteristic of its history, that goes beyond the narrative of the actors involved. Secondly, a group can have a centre of gravity, but this shifts over time as the group evolves. The scientific enterprise is then faced with the challenge of the transmission of its project, which calls for a redefinition of the original project, or even its elimination. Finally, there is the competitive nature of institutional enterprises. Focussing on a sole enterprise carries the risk of concealing competition from rivals disputing access to resources, both symbolic and material. This competition is vital when it comes to understanding how projects adapt to prevailing conditions. Besides, the institutional creations based on agreements that mix several, perhaps contradictory, logics may not satisfy anyone although they are supposed to satisfy everyone. This gap is also a dynamic factor since it means putting a new project on the drawing board.

This triple challenge faced by the institutional enterprise - collective vs. personification, transmission $v s$. liquidation, competition $v s$. deal - implies a historical analysis insofar as the 
enterprise inevitably becomes synchronic. It builds up over time and, in the case of science, even in the medium to long-term. Indeed the time that elapses between the moment when an institution is planned and its implementation is protracted because the ability to switch actors depends on the time needed for them to accumulate material or symbolic resources. The speed of this process of accumulation clearly depends on the field of activity and its environment. In France during the first half of the 20th century, the scientific community was characteristically long in the tooth (Pestre 1992). All members of the Academy of Sciences elected after 1920 were over the age of forty at the time of their election, and this was exacerbated by the massive loss of life during the war. Time was needed to be able to compete with patrons in place and who had begun their careers before World War I. Naturally, younger actors can always compensate for a shortage of actors by resorting to support outside the scientific field. Yet opportunities still appear particularly at the political level.

Another trait of institutional enterprise is contingence. Events which are exogenous to a given institution or field of activity upset the field of possibilities and thereby create new occasions for institutional entrepreneurs to seize. The war was thus the moment various scientific entrepreneurs try to exploit. The birth of an institution often occurs with a combination of circumstances which historical analysis can describe and explain. Naturally, this role of contingency does not create total uncertainty since the projects of institutional entrepreneurs pre-existed in one or other trigger factor. Neither does it produce total irreversibility. If an institution is born thanks to a favourable occasion seized by an entrepreneur, it can only survive thanks to a process of investment vital for its preservation as reflected in the activity of Jules-Louis Breton. The institutional enterprise thus consists of producing a project, exploiting the moment and registering its action in time. It is a process which lends itself to historical analysis.

What still needs to be understood is the precise nature of the scientific enterprise without falling into the trap of an a priori definition of science. One of the basic features of contemporary science is the morphology of the groups that practice it. The science that emerges in the early 20th century stands out for the ever increasing costs of technical equipment which became increasingly necessary in some disciplines, particularly physics. Furthermore, the scientific institutions also experienced an increase in the numbers of their staff which altered internal hierarchical relations. It is not surprising that the 20th century witnessed the emergence of the question of intellectual work or scientific unionism. Yet, if we cannot deny that a hierarchical principle of a new type emerges in laboratories or institutes, the organization of science at a national level has to face the fact that its 'patrons' do not have a hold over one 
another, especially when they belong to different disciplines. Why should a Nobel Prize for Physics be any better than a Nobel Prize for Chemistry? The accumulated scientific capital was not enough to prevent competition among actors whose enterprises could cancel each other out. This situation meant that they had to find the necessary support to implement their institutional enterprises outside their field. This organizational problem accounts for the alliance between the state and science in the 20th century.

An alternative way to mobilize resources is to highlight the benefits of science, which depend on the antagonism between 'pure' and 'applied', 'disinterestedness' and 'profit'. Of course, such a tension is implemented in a very historical context but the tension in itself shapes the possible profits of scientific institutional entrepreneurship. We have seen how the organization of French science generates platitudes even based on the institutionalization of these distinctions, and particularly that which distinguishes 'pure science' from 'applied science'. French science has also its historical semantics (for the US and German case, see Schauz 2014). In fact, the scientific enterprise is a very particular type of enterprise: an ongoing enterprise whose applications are not visible a priori, but which can produce results $a$ posteriori. The scientific enterprise thus defends itself on two fronts: the defence of disinterested science that requires financing in the name of high cultural values, on the one hand, and by illustrating the benefits of science that legitimates not only past, but also future, investments, on the other. This is why French men of science have played on both these registers. This may seem to favour institutional enterprises in the scientific domain since it allows scientists to mobilize policymakers in the name of the logic of free access and the name of that of interest. Yet this duality can backfire since these two logics may cancel each other out. If the logic of interest and utility prevails it thus divert those ready to support it in the name of the logic of free access ('If science is useful, you just have to charge those who use it'). On the other hand, the institutional scientific enterprise than has to join the duality of this discourse.

\section{References}

Anizan, A.-L. and P. Bernstein. 2012. Paul Painlevé: science et politique de la Belle Epoque aux années trente. Rennes: Presses Universitaires de Rennes, DL 2012.

Appell, P. 1923. Souvenirs d'un Alsacien. 1858-1922. Paris: Payot.

Belot R. 2000. 'Quand l'Académie des sciences découvre la technologie'. In La technologie au risque de l'histoire, 415-27. Paris: Berg. 
Blancpain, F. 1974. 'La création du CNRS: histoire d'une décision (1901-1939)'. Bulletin de l'Institut international d'administration publique, 32: 93-143.

Bret, Patrice. 2002. L'État, l'armée, la science. L'invention de la recherche publique en France. Rennes: Presses Universitaires de Rennes.

Charle, Ch. 1994. La république des universitaires, 1870-1940. Paris: Seuil.

Chatriot, A. 2006. 'Entrepreneurs de réforme et innovations organisationnelles dans l'entredeux-guerres'. Revue française d'administration publique 120: 635-50.

Crosland, Maurice. 1976. 'Science and the Franco-Prussian war'. Social Studies of Science 6 (2): 185-214.

Crosland, M. and A. Gálvez. 1989. 'The Emergence of Research Grants within the Prize System of the French Academy of Sciences, 1795-1914'. Social Studies of Science 19(1): 71-100.

Druelle-Korn, C. 2012. 'De la pensée à l'action économique: Étienne Clémentel (1864-1936), un ministre visionnaire'. Histoire@ Politique, 16: 40-54.

Fridenson, P. 1977. 1914-1918, l'autre front. Paris : Les Éditions ouvrières.

Galvez-Behar, G. 2008. La République des inventeurs. Propriété et organisation de l'innovation en France (1791-1922). Rennes: Presses universitaires de Rennes.

Guthleben, D. 2013. Histoire du CNRS de 1939 à nos jours. Une ambition nationale pour la science. Paris: A. Colin.

Henry, O. 2013. Les guérisseurs de l'économie: Ingénieurs-conseils en quête de pouvoir. Paris: CNRS.

Horne, J. 2004. Le Musée social: Aux origines de l'Etat-providence. Paris: Belin.

Le Chatelier, H. 1914 "Les encouragements à la recherche scientifique", Musée social. Mémoires et documents : 58-88.

Letté, M. 2004. Henry Le Chatelier (1850-1936) ou la science appliquée à l'industrie. Rennes: Presses universitaires de Rennes.

MacLeod, R. 2009. 'The scientists go to war: revisiting precept and practice, 1914-1919'. Journal of War \& Culture Studies 2(1): 37-51.

Merton, R.K. 1973. The Sociology of Science: Theoretical and Empirical Investigations. Chicago, IL: University of Chicago Press.

Moissinac, Ch. and Y. Roussel. 2010. Jules-Louis Breton (1878-1940): un savant parlementaire. Collection Carnot. Rennes: Presses universitaires de Rennes.

Morize-Charpentier, M. 1997. Jean Perrin, 1870-1942: savant et homme politique. Paris: Belin. Nye, M.J. 1986. Science in the Provinces. Berkeley: University of California Press. 
Paul, H.W. 1985. From Knowledge to Power: The Rise of the Science Empire in France, 18601939. Cambridge, UK: Cambridge University Press.

Pestre, D. 2015. Histoire des sciences et des savoirs. Paris: Seuil.

Pestre, D. 1992. Physique et physiciens en France: 1918-1940. Paris: Éditions des archives contemporaines.

Pestre, D. 1997. 'The Moral and Political Economy of French Scientists in the First Half of the 20th Century'. History and Technology 13(4): 241-48.

Picard, J.-F. 1990. La république des savants: la recherche française et le CNRS. Paris: Flammarion.

Pinault, M. 2006. La science au Parlement: les débuts d'une politique des recherches scientifiques en France. Paris: CNRS éditions.

Roussel, Y. 1985. 'Mode d'élaboration des politiques scientifiques en France au XXe siècle. DEA, École des hautes études en sciences sociales.

Schauz, Désirée. 2014. «What Is Basic Research? Insights from Historical Semantics ». Minerva 52 (3): 273-328. doi:10.1007/s11024-014-9255-0.

Shinn, T. 1993. 'The Bellevue grand électroaimant, 1900-1940'. Historical Studies of the Physical Science $\underline{\underline{s}}, 24: 157-188$

Topalov, C. 1999. Laboratoires du nouveau siècle. La nébuleuse réformatrice et ses réseaux en France, 1880-1914. Paris: Editions de l'Ecole des Hautes Etudes en Sciences Sociales.

Weart, S. 1979. 'Jean Perrin and the Reorganization of Science'. Physics Today 32(6): 42-51.

Weisz, G. 1983. The Emergence of Modern Universities in France, 1863-1914. Princeton, NJ: Princeton University Press.

Gabriel Galvez-Behar is associate professor at the University of Lille and member of the Institut Universitaire de France. His research focuses on the history of innovation and particularly on the relationship between intellectual property and scientific institutions. On these issues, he recently published 'Managing scientific patenting in French research organizations (1916-1951)'. Entreprises et Histoire, 82, 2016 : 89-102. 